\title{
Islamic Sukuk and Its Role in Supporting the Budget Deficit: Case Study on The Central Bank in The Jordan
}

\author{
Dr. AbedalfattahZuhair Al-abedallat \\ Faculty of Business and Finance, the World Islamic Sciences \& Education University \\ P.o.box-Amman, 11947 Jordan
}

Tel: 962-79-741-2547Ｅ-mail:Abdmm1968@yahoo.com

Received: May 25, 2016 Accepted: Sep 23, $2016 \quad$ Published: October 1, 2016

doi:10.5296/jmr.v8i4.9606

URL: http://dx.doi.org/10.5296/jmr.v8i4.9606

\begin{abstract}
Market Sukuk (Arabic word meaning bond) grown very large in the recent period, which is similar to conventional Eurobonds, Islamic Sukuk increased in the current period, and it is a good substitute for conventional bonds, but in Jordan instruments Islamic Market still suffers a lot of obstacles, though that Jordan suffers greatly from debt and increasing annually, but there is no practical step by the central bank to issue instruments Islamic alternative for the issuance of government bonds.

The purpose of the study to investigate the obstacles that prevented the issuance of central bank for those instruments, and the study approach is the Data was collected by two methods first, primary data was collected using questionnaire, second, secondary data was collected using literature.

The study found that there are obstacles prevented the issuance of central bank the instruments Islamic including: regulatory risk, and liquidity risk, and regulatory obstacles, and the cost of issuance, and the research has recommended that: the central bank should prepare the laws to issuance Islamic sukuk, and the central bank should encourage the Islamic banks to issuance Islamic sukuk.
\end{abstract}

Keywords: Sukuk, centralbank,Bank, Islamic bond,budget deficit, monetary policy 


\section{Introduction}

Market Sukuk (Arabic word meaning bond) grown very large in the recent period, which is similar to conventional Eurobonds, the history of the Sukuk in Malaysia in 2002 when it was issued nearly a billion dollars, of which, the volume of it grew at high rates, even exceeded 94 billion dollars in 2007 . Islamic Malaysian banks have occupied the first place in the versions of Sukuk since 2002 and comes after the Islamic banks in the United Arab Emirates, and then after a large margin of banks, Saudi Arabia .

The idea of Islamic instruments came to meet the economic and investment needs at the present time, so as to contribute in the development and investment but in accordance with the provisions of Islamic Sharia law, and is expected to be the size of issuing the sukuk up to three trillion dollars by the year 2015 (dabag,2011).

With the growing volume of indebtedness of the Jordan and access to more than 75 percent of GDP, which is a candidate because up to 80 percent by the end of this year if it continues the pace of borrowing in this way, the urgent need for the government to search for new sources of funding to meet its expenses increased, from Here came the idea of Islamic Sukuk to be a window for financing new projects that are no longer able to provide the facilities from borrow traditional.

Lynette Capital Investments - the investment arm of Capital Bank - for achievement unprecedented investment in the Kingdom; management and arrangement of the first Islamic Sukuk in Jordan worth 85 million Jordanian dinars for a period of 7 years, in favor of $\mathrm{Al}$ Rajhi Cement Company.

Participated in this version elite of Islamic and commercial banks included Capital Bank and the Cairo Amman Bank and the Bank of Jordan and the Islamic International Arab Bank and Union Bank and Jordan Kuwait Bank and Jordanian Islamic Bank.

The problem of this study there is no issue of the sukuk in Jordan despite the need in the state, represented by the central bank for liquidity, the objectives of the study to answer the following questions:

1-What is the size of the debt in Jordan and what a way to borrow to pay off the deficit in the budget.

2 - What is the reality of Islamic Sukuk in Jordan?

3 - Is there a need to issue Sukuk in Jordan for central banks?

4 - What are the obstacles to issue the Islamic instruments from the perspective of central bank?

2 - The theoretical framework

1. Concept

The number of banks in Jordan are a twenty-six banks, broken down as follows: 13 Jordanian commercial banks, and 9 foreign commercial banks, and two Islamic Jordanian banks and 
two foreign Islamic bank, these banks are: IJordan Dubai Islamic bank, Al-Rajhi bank, Jordan Islamic bank, Islamic international Arab bank(www.cbj.gov.jo.com),

Jordanian Central Bank Act was passed in 1959, and in 1962 the Council of Ministers asked the Council of monetary to prepare for the establishment of the Central Bank, and in 1963 was the central bank's founding and was appointed governor and his board of directors, but the central bank started in 1964, where he has been resolved Monetary Council (Ramadan \&Goda, 2103,195-196).

Central Bank of Jordan aims to accomplish many goals represented in Article IV of the Central Bank Law (monetary policy):

1-The maintain monetary stability in the kingdom.

2-The stability of exchange of dinar.

3-encouraging the economic growth.

The goal of monetary stability to encourage domestic and foreign investment, which leads to stimulate the economy

(Abdullah \&Trad, 2006,31-32).

The Public debt of the Jordan, as is the situation at the end of 2013 is 19098.5 million dinars, or $80 \%$ of GDP, compared with $75.5 \%$ of GDP at the end of 2012 , and is a domestic public debt is 11862 million and around $68 \%$ of total debt is Treasury bills and bonds (Annual Report of the Central Bank, 2013).

The problem of the research is the absence of Issuance of the Central Bank the Islamic bonds to be an Islamic alternative to conventional interest-bearing bonds, and this research highlights the tenuous Islamic instruments and their role in supporting the public budget.

The financial Accounting Islamic institutions defined the Sukuk as: documents of equal value representing the common shares in the ownership of objects or benefits or services or in the assets of a particular project or investment activity particularly after the collection of valuable instruments and lock the door underwriting and start using as issued for him, the goal of the sukuk is to get liquidity and aggregation the savings, and there are types of Islamic instruments including the following:

1-Ijara sukuk: defined as equal value of securities, there are types of her instruments are equity assets, ownership services instruments.

2. Murabahasukuk: defined as equal value of securities are issued to finance the purchase of goods so that the commodity Murabaha be owned campaign instruments.

3-speculative sukuk: an equal value of securities representing projects or activities that are managed on the basis of the agreement with the provisions of Islamic Sharia.

4. mushakasukuk: It is of equal value securities are issued to use the proceeds to create a project, or develop an existing project or activity and financing of the project assets become 
the property of the campaign instruments depending on their shares.

5. Agency sukuk: it is an equal value of the securities representing the projects or the activities are managed on the basis of the agency of the investment (naser\&zaid, 2013).

Developed countries and developing countries interested in the financial markets where the capital market is a mirror of the economy and the markets have a large role in mobilizing savings and direct them towards investment thus supporting the national economy therefore it benefit the community (samoor, 2007).

The Islamic instruments explore to different risks can be divided as follows:

1. Financial risk: the risk related to the management of assets and liabilities and the most important sources of financial risks:

A- The credit risk: These are called also funding risk is defined as the risk of non-payment of the debtor's part or all credit on time agreed upon in investments Murabaha when is the promise of a non-binding, the credit risk arises in case the client does not wish to receive the item purchased or unwillingness in receipt of item that has been in the investment industry Istisna' a sukuk, it is the most important forms of credit risk:

1-risk delays in the fulfillment: this is expected in the case of sukuk that drive revenue, which distributes them will be delayed several months because of the debtor's desire to delay.

2-risk of inability to fulfill this happens if the expected campaign instruments that are bankrupt debtor and this risk depend on the creditworthiness of the debtor, and this is linked to the credit classifications by insurance companies.

(B) Market risk: is the systemic or public risk arising because of general economic or political factors and the most important market risk:

1- Real asset market risk (goods and services), and this risk comes from the fact that sukuk(instruments )represent a common share in the ownership of assets and not a religion thus subject to factors related to supply and demand, for example.

2- Money market risk: include exchange rate risks that arise as a result of currency exchange rates fluctuate, and also examples return rate risk refers to the risk that the actual difference in yield for the expected return.

3-Securities price risk: a risk of change the market value of the instruments of Islamic.

4-Inflation risks: the risks related to lower purchasing power of the currency as a result of the continuing rise in the general level of prices.

(C) Liquidity risk: It is related to unable of the company to meet its liabilities In the case of the Islamic sukuk are low because the source of it is the state, that means in the case of instruments is the inability of the bondholders to convert sukuk into cash.

Second: Operational Risk: classifies this type of risk if by general factors within the general risks and examples of natural disasters such as wars, or it have classified as special risk if due 
to internal factors such as corruption receivables or weakness of the Shari'a, and for instruments Islamic this type of risk is at its lowest level, only when it comes to factors related to general out of control, such as war.

Third: the risks associated with formulas Islamic Finance: They are linked formulas financing risks underlying Islamic sukuk, and for examples the Investment speculative risks, and the most prominent risk is moral hazard represented in the speculator fraud and non-compliance with terms of the contract, and it may be lead to a decline the market value of the instruments of speculation in financial markets, as well as examples of Murabaha investment risk arises from the inability of a customer's obligation to pay premiums on time.

Fourth: The legitimacy of risk: the risk can be included under company risk may arise from many factors such as: risks related to the legitimate differences among scholars as a result of the lack of legitimacy of the uniform standards, and the risk of conflicts of interest in the religious bodies (Nasser\& Zaid, 2012).

\section{Previous Study}

There is many studies that addressed the subject Islamic sukuk (bond) and its role in supporting the budget deficit, and the most important of these studies are:

1 - Study (al-amine, 2008): entitled "Sukuk market: innovation and challenges : This paper discusses some of these important issues, it deals with the issues of capital guarantee, contractual structures, pricing, and asset substitution in case of ijarahsukuk, musharakahsukuk, and their various forms .It also covers the issues rating of sukuk, harmonization of sharaiah rules, and problems involved in defining the governing law for sukuk issuance.

2 - Study (saripudinetal., 2012): entitled "Application of promise in sukukmusharakah structure" Sukukmusharakah is an instrument of Islamic capital market .It is a preferred sukuk to be issued internationally or locally since the year 2005 .This study therefore aims to analyze the application of promise in structuring sukuk in malaysia. The study has identified that the concepts of promise in which consists of wa'd .wa'dan and muwa'adah are valid and recognized by islamic jurisprudence to be implemented in sukukmusharakah .

3 - Study (shahimietal. 2012) entitled "Sukuk defaults and its implications: a case study of malaysian capital market " this paper aims to discuss the issue of sukuk default and its implication on Malaysian capital market. And discuss the impact of risk of sukuk on the country. This study will help sukuk issuers and rating agencies for estimation of credit risk and setting corporate pricing.

4. Study (Nasser \& Zaid, 2012) entitled: risk management instruments Islamic government: a study on the Islamic government in Sudan instruments The study concluded to the importance of Islamic instruments as a quantum leap in the development of Islamic financial instruments, and also that the issuance of Islamic instruments linked to group of the financial and operational risks, the researcher has recommended the need for classification of the Sudanese government credit instruments by the international rating agencies. 
5. Study (moshtaha, 2007), entitled: The role of Islamic banks in advancing local investments in Palestine, the study aimed to identify the work of Islamic banks in Palestine in terms of the nature of the work, activities and modes of funding which, the study concluded that Islamic banks contribute to the GDP is slim, and that Islamic banks rely on short-term investments significantly in funding.

6. Study (Bokhari \& Aib, 2011) entitled: mechanisms of financial engineering as a tool to manage the risk of Islamic instruments and the impact of the financial crisis on market instruments, Islamic, the researcher spoke about the concept of financial engineering and enablers to the emergence of financial engineering Islamic legitimate and rooting, and research found that financial engineering took its principles derived from Islam, which calls for the update values, and also study concluded that the Islamic instruments could be a substitute for conventional bonds but is facing a range of instruments, like risk of financial investments.

7-study (Nasser \& Zaid, 2013), entitled: the role of governance in risk instruments Islamic administration, the study take Islamic instruments, and its importance, and the concept of corporate governance and the concept of risk instruments Islamic governance mechanism for risk management instruments Islamic ones, the study concluded that there defect and failure in the process of organizing the issuance of Islamic bonds trading process and that moral hazard, administrative and conflicts of interest in the legal bodies of the most important risks that can be addressed governance.

\section{Hypotheses}

for studying Barriers of the expansion in issuance the Islamic sukuk, we test the following hypotheses:

H01 - There is no statistical relationship between the existence problems related to the ability of the central bank to issuance the sukuk (, Regulatory constraints, legal impediments, the weakness of trained talent, problems with credit rating, Problems relating to Islamic finance formulas, problems related to conflicts of interest in the Sharia Supervisory Board) and the expansion of central bank in the issuance of Islamic sukuk.

H02 - There is no statistical relationship between the existences various risks (Credit risk, exchange rate risk, the risk of rising costs of issuance, inflation risk, liquidity risk) and the expansion of central banks in the issuance of Islamic sukuk.

\section{Research Method}

1 - Methodology of the study:

For the purposes of testing hypotheses of the study, the study relied descriptive and analytic method, as well as field research, With regard to side the descriptive, the study gave an accurate picture of Barriers of expansion of the Islamic sukuk (Islamic bond), and through previous studies, as for the side of the field, the study relied on a questionnaire designed in order to collect the necessary data to test hypotheses. 
2 - The population of study (Scope of the research):

The population of study represents the central banks in the Jordan, which offers various banking services to all banks in the Jordan, where the researcher distributed a questionnaire to obtain information about the study.

3 - Tools of Study:

The researchers designed a questionnaire to solicit the views of employee of Islamic banks about the study through likert scale, the study distributed (140) questionnaire has been recovered (130), and the percentage is $93 \%$.

4 - Sincerity and persistence of the study tool:

A tool of the study (a questionnaire) has been showed on a group of arbitrators (5 experts), to ensure the veracity of content resolution and good drafting, and representation of the subject accurately, The reliability coefficient of the questionnaire according to the coefficient (Cronbach alpha) is (91\%) through the statistical analysis of the study's sample.

\section{The Results of Hypothesis Testing}

In this section of study we present analysis the results of research hypotheses. As mentioned before, for testing $\mathrm{H} 01, \mathrm{H} 02$, we also use a sample of employee of the central bank, the following subsections provide analysis of results of hypotheses testing at total sample level.

This section contains the results of the research aimed to know the Barriers of expansion of the Islamic sukuk, it also includes a description of the personality variables for members of the study sample, and the researcher used the program of statistical analysis (SPSS), to extract the averages, arithmetic, and standard deviations of the paragraphs of the a questionnaire, The following is a presentation of the demographic variables according to Table 1: 
Table 1. Distribution of study sample according to demographic variables

\begin{tabular}{|l|r|r|}
\hline Variable & Frequency & Percentage $\%$ \\
\hline 1-gender & 100 & $77 \%$ \\
\hline Male & 30 & $23 \%$ \\
\hline Female & 7 & $5 \%$ \\
\hline 2- job site & 20 & $15 \%$ \\
\hline Manager department & & \\
\hline $\begin{array}{l}\text { Assistant manager of the } \\
\text { Department }\end{array}$ & 60 & $46 \%$ \\
\hline Head department & 42 & $34 \%$ \\
\hline Employee & 7 & $5 \%$ \\
\hline 3-Acadimic Qualifications & 88 & $67 \%$ \\
\hline Graduates (PhD or Master) & 35 & $28 \%$ \\
\hline Baclores & & $8 \%$ \\
\hline Diploma or less & 10 & $30 \%$ \\
\hline \multicolumn{1}{|c|}{ 4-Years of experience } & 39 & $19 \%$ \\
\hline 5 years or less & 25 & $43 \%$ \\
\hline More than 5to10 years & 56 & \\
\hline More than 10to15 years & & \\
\hline More than 15 years & & \\
\hline
\end{tabular}

\subsection{Results of Testing H01}

$\mathrm{H} 01$ :There is no statistical relationship between the existence problems related to the ability of the central bank to issuance the sukuk (Regulatory constraints, legal impediments, the weakness of trained talent, problems with credit rating, Problems relating to Islamic finance formulas, problems related to conflicts of interest in the Sharia Supervisory Board )Table (2) shows the results of answers to the questions of the hypothesis. 


\section{Macrothink}

Table 2. The results of answers to the questions of the hypothesis

\begin{tabular}{|c|c|c|c|}
\hline Number & Paragraph & $\begin{array}{c}\text { Arithmetic } \\
\text { Averages }\end{array}$ & $\begin{array}{c}\text { Standard } \\
\text { Deviations }\end{array}$ \\
\hline $1-$ & $\begin{array}{l}\text { The regulatory constraints lead to a reduction in } \\
\text { issuance of Islamic sukuk. }\end{array}$ & 3.99 & .95 \\
\hline $2-$ & $\begin{array}{l}\text { The legal impediments lead to reduction of } \\
\text { issuance of Islamic sukuk. }\end{array}$ & 3.80 & 1.06 \\
\hline $3-$ & $\begin{array}{l}\text { The obstacles related to the lack of trained } \\
\text { administrative efficiencies lead to a reduction in } \\
\text { the issuance of Islamic sukuk. }\end{array}$ & 3.96 & .99 \\
\hline 4- & $\begin{array}{l}\text { The obstacles related to the lack of credit rating } \\
\text { instruments Lead to a reduction in the issuance of } \\
\text { Islamic Sukuk. }\end{array}$ & 3.28 & 1.09 \\
\hline $5-$ & $\begin{array}{l}\text { The obstacles related to Islamic finance formulas } \\
\text { such as: risks moral speculation and lack of } \\
\text { commitment to the contract will lead to reducing } \\
\text { the issuance of Islamic sukuk. }\end{array}$ & 3.46 & .99 \\
\hline $6-$ & $\begin{array}{l}\text { There are obstacles related to the Supervisory } \\
\text { Board of legitimacy such as the differences } \\
\text { between the legal scholars as a result of the } \\
\text { absence of uniform standards of legitimacy lead to } \\
\text { reduction in the issuance of Islamic sukuk. }\end{array}$ & 3.91 & 1.1 \\
\hline & Average & 3.733 & \\
\hline
\end{tabular}

We notes from the previous table no. (2), which includes paragraphs that test the first hypothesis that the Arithmetic Averages ranged between 3.28-3.99, and the highest average is paragraph No. 1, which states (The regulatory constraints lead to a reduction in the Islamic Sukuk.) And was the lowest average is for the paragraph No. 2, which states (The obstacles related to the lack of credit rating sukuk Lead to a reduction in the issuance of Islamic instruments) . and in general, all averages were higher than Class 3, and that the overall average of the paragraph are 3.733 . 
Table 3. The results of answers to the questions of the hypothesis

\begin{tabular}{|r|c|c|c|}
\hline Number & \multicolumn{1}{|c|}{ Paragraph } & $\begin{array}{c}\text { Arithmetic } \\
\text { Averages }\end{array}$ & $\begin{array}{c}\text { Standard } \\
\text { Deviations }\end{array}$ \\
\hline $12-$ & There is weakness in issue the Islamic sukuk. & 3.46 & .97 \\
\hline $13-$ & $\begin{array}{l}\text { The central bank doesn't make any issue the } \\
\text { Islamic sukuk. }\end{array}$ & 3.56 & .91 \\
\hline $14-$ & $\begin{array}{l}\text { The central bank has obstacles that don't issue } \\
\text { Islamic sukuk. }\end{array}$ & 3.79 & .71 \\
\hline $15-$ & $\begin{array}{l}\text { The Islamic sukuk is tool to supporting the } \\
\text { budget deficit. }\end{array}$ & 3.37 & .82 \\
\hline $16-$ & $\begin{array}{l}\text { The Islamic bonds to be an Islamic alternative to } \\
\text { conventional interest-bearing bonds. }\end{array}$ & 3.94 & \\
\hline $17-$ & The Islamic sukuk have cost for issue. & 3.47 & 3.59 \\
\hline Average &
\end{tabular}

We notes from the previous table no. (3), which includes paragraphs that test the first hypothesis that the Arithmetic Averages ranged between 3.37-3.94, and the highest average is paragraph No. 16, which states (The Islamic bonds to be an Islamic alternative to conventional interest-bearing bonds) . And in general, all averages were higher than Class 3, and that the overall average of the paragraph is 3.59. And this refers to the rejection of the null hypothesis and accepts the alternative hypothesis.

To test the first hypothesis been used correlation test and the result as table no (4).

Table 4. Correlations

\begin{tabular}{|ll|c|l|}
\hline & & Problems & Issuance the sukuk \\
\hline problems & Pearson correlation & 1 & 0.77 \\
& Sig (2-tailed) & & .001 \\
& $\mathrm{~N}$ & 130 & 130 \\
\hline & Pearson & .77 & 1 \\
correlation & & .001 & \\
Issuance & Sig (2-tailed) & 130 & 130 \\
& $\mathrm{~N}$ & & \\
& & & \\
\hline
\end{tabular}

The value of Pearson correlation is .77, and this refers to good relation between problems and issuance the sukuk, and this lead to rejection the null hypothesis and accepts the alternative hypothesis.

\subsection{Results of Testing H02}

H02 - There is no statistical relationship between the existences various risks(Credit risk, exchange rate risk, the risk of rising costs of issuance, inflation risk, liquidity risk) and the expansion of central banks in the issuance of Islamic sukuk, table (5) Shows the results of 
answers to the questions of the hypothesis .

Table 5. The results of answers to the questions of the hypothesis

\begin{tabular}{|r|c|c|c|}
\hline Number & \multicolumn{1}{|c|}{ Paragraph } & $\begin{array}{c}\text { Arithmetic } \\
\text { Averages }\end{array}$ & $\begin{array}{c}\text { Standard } \\
\text { Deviations }\end{array}$ \\
\hline $7-$ & $\begin{array}{c}\text { The risk of default (credit risk) leads to a } \\
\text { reduction in the issuance of Islamic sukuk. }\end{array}$ & 3.44 & .99 \\
\hline $8-$ & $\begin{array}{l}\text { The risks related to Change Currency exchange } \\
\text { rates lead to a reduction in the issuance of Islamic } \\
\text { sukuk. }\end{array}$ & 3.50 & .90 \\
\hline-9 & $\begin{array}{l}\text { The Risk-related increase the costs release will } \\
\text { lead to reduction in the issuance of Islamic sukuk. }\end{array}$ & 3.70 & .79 \\
\hline $10-$ & $\begin{array}{l}\text { The risk related to decline of purchasing power } \\
\text { of the currency (inflation risks) lead to a reduction } \\
\text { in the issuance of Islamic sukuk. }\end{array}$ & 3.30 & .83 \\
\hline $11-$ & $\begin{array}{l}\text { The Risk related to liquidity of the inability of the } \\
\text { instrument holder to convert it into cash lead to a } \\
\text { reduction in the issuance of Islamic sukuk. }\end{array}$ & 3.90 & \\
\hline & Average & 3.568 & \\
\hline
\end{tabular}

We notes from the previous table No. (5), which includes paragraphs that test the second hypothesis that the Arithmetic Averages ranged between 3.3-3.9, and the highest average is the paragraph No. 11, which states (The Risk related to liquidity of the inability of the instrument holder to convert it into cash lead to a reduction in the issuance of Islamic sukuk.)

And was the lowest average is the paragraph No. 10, which states (The risk related to decline of purchasing power of the currency (inflation risks) lead to a reduction in the issuance of Islamic sukuk), and in general, all averages were higher than Class 3, and that the overall average of the paragraph are 3.568 . 
Table 6. The results of answers to the questions of the hypothesis

\begin{tabular}{|r|c|c|c|}
\hline Number & \multicolumn{1}{|c|}{ Paragraph } & $\begin{array}{c}\text { Arithmetic } \\
\text { Averages }\end{array}$ & $\begin{array}{c}\text { Standard } \\
\text { Deviations }\end{array}$ \\
\hline $12-$ & There is weakness in issue the Islamic sukuk. & 3.46 & .97 \\
\hline $13-$ & $\begin{array}{l}\text { The central bank doesn't make any issue the } \\
\text { Islamic sukuk. }\end{array}$ & 3.56 & .91 \\
\hline $14-$ & $\begin{array}{l}\text { The central bank has obstacles that don't issue } \\
\text { Islamic sukuk. }\end{array}$ & 3.79 & .69 \\
\hline $15-$ & $\begin{array}{l}\text { The Islamic sukuk is tool to supporting the } \\
\text { budget deficit. }\end{array}$ & 3.37 & .82 \\
\hline $16-$ & $\begin{array}{l}\text { The Islamic bonds to be an Islamic alternative to } \\
\text { conventional interest-bearing bonds. }\end{array}$ & 3.94 & \\
\hline $17-$ & The Islamic sukuk have cost for issue. & 3.47 & 3.59 \\
\hline Average &
\end{tabular}

We notes from the previous table no. (6), which includes paragraphs that test the first hypothesis that the Arithmetic Averages ranged between 3.37-3.94, and the highest average is paragraph No. 16, which states (The Islamic bonds to be an Islamic alternative to conventional interest-bearing bonds). And in general, all averages were higher than Class 3 , And this refers to the rejection of the null hypothesis and accepts the alternative hypothesis.

To test the second hypothesis been used correlation test and the result as table no (7).

Table 7. Correlations

\begin{tabular}{|l|c|l|l|}
\hline & & Risks & Issuance the sukuk \\
\hline Risks & Pearson correlation & 1 & 0.797 \\
& Sig (2-tailed) & & .001 \\
$\mathrm{~N}$ & 130 & 130 \\
& & \\
\hline \multirow{3}{*}{ Issuance } & Pearson correlation & .797 & 1 \\
& Sig (2-tailed) & .001 & \\
$\mathrm{~N}$ & 130 & 130 \\
& & \\
\hline
\end{tabular}

The value of Pearson correlation is .797 , and this refers to good relation between risks and issuance the sukuk, and this lead to rejection the null hypothesis and accepts the alternative hypothesis.

\section{Summary and Concluding Remarks}

The results (findings):

1-There are obstacles to the expansion of the central banks in the issuance of Islamic sukuk are the organizational obstacles, legal, and the weakness of trained talent, and problems related to credit rating, and problems related to Islamic financing formulas, and problems 
related to conflicts of interest in the Sharia Supervisory Board.

2-There are obstacles (risks) to the expansion of the central banks in the issuance of Islamic Sukuk as: credit risk, exchange rate risk, the risk of rising costs of issuance, inflation risk, and liquidity risk.

3-The study rejected of the null hypothesis and accepted the alternative hypothesis for the two hypotheses.

4- There is statistical relationship between relationship between the existence problems related to the ability of the bank to issuance the sukuk and the expansion of central banks in the issuance of Islamic sukuk.

5- There is statistical relationship between the existences various risks and the expansion of central banks in the issuance of Islamic sukuk.

Research has recommended the following:

1 - The central bank should prepare the laws to issuance Islamic sukuk.

2-The central bank should encourage the Islamic banks to issuance Islamic sukuk.

3 - The central bank should train their employees about the marketing of those instruments Islamic.

4 - The central bank should do hedge about the risks for the issuance of Islamic Sukuk

\section{References}

Al-amine, Muhammad. (2008). Sukuk market: innovation and challenges. Islamic economic studies, 15(2), 2-3.

Abdullah, Khalid Amin, \& the trad, Ishmael. (2006). Manage banking operations, 1st edition, Amman, Jordan: Dar Wael for publication.

Ab majid, Hafizi, shahimi, Shahida, \& Abdullah, Mohd. (2012). Sukuk defaults and its implications: acase study of malaysian capital market, $8 \mathrm{Th}$ international conference on Islamic and finance 2-3.

Bokhari, Lahlou, \& Aib, Walid. (2011). Mechanisms of financial engineering as a tool to manage the risk of Islamic Sukuk and the impact of the financial crisis on market instruments. the First International Meeting of the Institute of Economic Sciences, the Ministry of Higher Education, Algeria.

Dabag, Ziad. (2011). Sukuk Islamic and its role in support of the general budget from perspective. The Islamic finance: Islam in Asia magazine, 1(8), 7-10.

Dagi, Ali Mohi El Din Qara. (2009). Islamic Sukuk "securitization" and contemporary applications - doctrinal study applied economic, Islamic Fiqh Academy. Central Bank of Jordan, (www.cbj.gov.jo.com).

Mohammad, Sami Youssef Kamal. (2010). Islamic financial instruments of the crisis - the 
director, (first edition). Cairo, Egypt: Dar Al alfekar Arab Thought.

Moshtaha, Bassam Bahauddin. (2011). Role of the Islamic banks in advancing local investments in Palestine, Master Thesis, Al-Azhar University, Gaza, Palestine.

Nasser, Soliman, \& Zaid, Rabia. ( 2013). The role of governance in management Islamic risk instruments. the Eighth International Scientific Conference, Faculty of Economic and commercial sciences, Hassiba Ben Bouali University, Algeria.

Ramadan, Ziad, \& Goda, Mahfouz. (2013). Contemporary trends in bank management, 4th edition, Amman, Jordan: Dar Wael for publication.

Saripudin, Khairun, mohamadShamsiah, Razif, \& Nor, Rosli, Sohan, Ahmad, Bahiya. (2012). Application of promise in sukukmusharakah structure. Middle -East Journal of Scientific research, 12(2). (Annual Report of the Central Bank: 2103)

Soliman, Nasser, \& Zaid Nasser. (2012). Risk management instruments Islamic government: a study on the Sudanese government instruments, Fifth International Conference on Islamic banking and Islamic finance titled. For risk management: regulation and supervision, Institute of Banking Studies, Amman, Jordan.

Samoor, Nabil. (2007). The Securities Islamic market between theory and application: Master Thesis, Islamic University, Gaza, Palestine. 